\title{
Repetiçấo, negaÇão e ideologia. Marx, Hegel e o PROBLEMA DO SUJEITO
}

\author{
Pedro Laureano ${ }^{1}$
}

Resumo: Este artigo parte da análise da influência de Hegel na construçấo do conceito de capital e de ideologia, na obra de Marx. Para tal, buscou-se analisar a passagem dos primeiros escritos humanistas de Marx à sua teoria tardia. Da ruptura realizada por Marx em relação a suas obras de juventude, surge o problema de como determinar o sujeito, uma vez que a perspectiva humanista inicial é abandonada. A ideia é a de que, paradoxalmente, quando critica a dialética hegeliana, Marx termina por encontrar problemas que poderiam ser resolvidos através de conceitos hegelianos, como a questấo do sujeito de classe. É o que procuraremos argumentar por meio de uma análise sobre o papel da negatividade em Hegel.

Palavras-Chave: Marx. Hegel. Dialética. Ideologia.

A forma como Marx (2010b) compreende a ideologia capitalista depende, fundamentalmente, de sua crítica do idealismo hegeliano. Quando elabora o conceito de capital, a ideia de Marx é a de que este já funciona de maneira próxima àquilo que Hegel (1991) chama de "espírito absoluto" (absolute Geist), um agente trans-histórico capaz de garantir que, através do negativo, das crises socais e da exploração, haverá progresso e reconciliação dos antagonismos sociais. Tal constatação ocorre quando Marx se afasta de seus escritos de juventude e percebe que a ideia de que a exploração seria fundamental ao processo histórico constitui a definição mesma da ideologia capitalista. Esta pode ser caracterizada como uma estranha mistura de cinismo e humanismo, a qual procura legitimar a exploraçáo como parte imanente do desenvolvimento social. Cinismo que Marx passa a associar aos limites do idealismo hegeliano.

1 Professor Adjunto do Departamento de Psicologia da Universidade Federal de São João del-Rei (UFSJ), São João del-Rei, MG - Brasil. E-mail: pedro@laureanopsi.com.br

Doutor em Psicologia Clínica pela PUC-RJ.

http://dx.doi.org/10.1590/0101-3173.2018.v41n3.06.p105

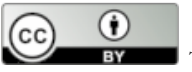

This is an open-access article distributed under the terms of the Creative Commons Attribution License. 
Procuraremos argumentar, entretanto, que quando Marx rompe com sua perspectiva humanista anterior, longe de afastar-se de Hegel, ele, na verdade, termina por encontrá-lo. E que o reconhecimento desse encontro poderia haver fornecido uma resposta para uma das questôes que nos parece não plenamente reconhecida, em sua obra madura, o problema de definir o sujeito de classe após o abandono do humanismo das primeiras obras.

De fato, Marx recusa a ideia, presente em seus primeiros escritos, de que o movimento histórico seria realizado conforme a dupla negaçáo colocada por Hegel no centro de sua filosofia. Nesse esquema que Marx importava de Hegel, a primeira mediação por meio do negativo corresponderia à alienação da produção na esfera objetiva do capital, no qual o sujeito produz para um outro; já a segunda negação, a "negação da negação", corresponderia ao movimento de suprassunçáo (Aufhebung) da oposição entre o sujeito e o outro, no qual a experiência da negatividade é, ao mesmo tempo, abolida e conservada: abolida enquanto alienação, mas conservada enquanto potência subjetiva de negação, de produção. A este momento corresponderia, então, uma síntese da diferença e da identidade, do eu e do outro, do objetivo e do subjetivo etc.

Trata-se do esquema clássico da dialética hegeliana, de reconciliação dos contrários. Procuraremos argumentar, entretanto, não apenas que a ruptura entre a obra humanista dos primeiros anos de Marx e seus escritos de maturidade depende da recusa desse esquema, mas também que tal dialética da reconciliação já não era presente na própria obra de Hegel. A respeito do primeiro ponto, veremos como, ao construir o conceito de capital, Marx enxerga como o papel da negatividade no progresso histórico já é inerente à própria sociedade capitalista, podendo caracterizar a ideologia própria ao sistema. A respeito do segundo, por sua vez, procuraremos articular a ideia de que o objetivo da dialética hegeliana é justamente recusar tal interpretaçáo da negatividade.

\section{UM RESTO QUE NÁO RECONCILIA}

Uma das características frequentemente utilizadas para se descrever a sociedade atual é aquela da crise das dicotomias que marcam a modernidade, quando não o próprio pensamento ocidental. Filósofos, como Deleuze (2006), apontam que a dialética hegeliana seria incapaz de compreender essa crise, já que estaria limitada à apreensão do conflito dentro de uma lógica opositiva, a qual tenderia à sua resolução através da síntese, ou da reconciliação 
dos opostos. Para esses autores, Hegel apenas pôde pensar a negatividade e a diferença a partir da ideia de oposição. Como assinala Deleuze, em Nietzsche e a filosofia, em um trecho em que polemiza com a dialética:

A oposição pode ser a lei da relação entre produtos abstratos, mas a diferença é o único princípio de gênese ou de produção, que produz ela mesma a oposiçáo como simples aparência [...] destituídas de sua pretensão em dar conta da diferença, a oposiçáo deixa de ser formadora, motora e coordenadora. (DELEUZE, 2001, p.181, tradução nossa).

Embora busque elevar a oposição ao conceito de uma contradição produtiva, a dialética seria incapaz de compreender uma sociedade em que a forma opositiva do conflito se apresenta em crise, de maneira que deveríamos elaborar outra concepção de diferença capaz de escapar ao quadro da metafísica hegeliana. É aquilo que Deleuze busca pensar através de conceitos como os de "diferença intensiva." (DELEUZE, 2006, p. 120).

Historicamente, poderíamos dizer que o argumento parte da constatação de que não há mais qualquer figura de alteridade capaz de desempenhar o papel de opositora dentro de uma narrativa histórica pensada como reconciliação do negativo. Ou, segundo a tese de Negri e Hardt (2000, p. 204), em Império, "não há mais fora", já que, na sociedade atual, nenhuma diferença seria irrecuperável e, portanto, nenhuma diferença seria capaz de determinar o conflito como oposição entre um dentro e um fora. Trata-se de um tempo histórico para o qual a dialética, assentada na ontologização do conflito e na elevação do negativo ao próprio absoluto, haveria se tornado não apenas supérflua como possibilidade de compreensão do social, mas francamente retrógrada. Incapaz de pensar outro modelo de diferença que não o da oposição e o da reconciliação, a dialética termina por evocar justamente aqueles aspectos $\mathrm{da}$ modernidade que a sociedade deveria, de alguma forma, superar.

Entretanto, se seguirmos os aspectos mais importantes da crítica de Marx a Hegel, podemos encontrar um diagnóstico aparentemente inverso àquele que é elaborado por Deleuze e Negri e Hardt. Para Marx, a dialética hegeliana deveria ser questionada justamente porque ela haveria sido realiza$d a$, porque ela já descreve o modo de funcionamento inerente à sociedade capitalista. É o que Marx percebe, em função daquilo que, mais adiante, veremos como sendo o movimento interno de autocrítica das categorias humanistas que haviam marcado seus primeiros escritos, como a Critica da filosofia de Hegel (2010a) e os Manuscritos econômico-filosóficos (2004). Que não haja al- 
teridade radical em relação ao capitalismo significa, para o Marx "tardio", dos Grundrisse (2011) e de O capital (2010b), não o fim das condiçóes históricas de possibilidade da dialética, todavia, de fato, que o capitalismo já é a realização daquilo que Hegel havia pensado em sua filosofia.

O capitalismo, para Marx, funciona como uma espécie de sujeito dialético, aquilo que, em $O$ capital, o filósofo chama de "sujeito automático" (MARX, 2010b, p. 185). O termo "sujeito", aqui, remete à ideia hegeliana de compreensão do sujeito como negatividade. De acordo com Hegel, não há sujeito autônomo, isto é, o sujeito apenas pode ser compreendido através da mediação que realiza com o outro. No início da Fenomenologia do espírito (1992), por exemplo, o Eu é caracterizado a partir de sua oposição em relação ao objeto. Tal oposição é pensada como uma negação, por intermédio da qual, entretanto, o sujeito é determinado. Isto é, a determinação do Eu é feita a partir do não eu - justamente, do objeto. É tal oposição, portanto, que irá acarretar na necessidade de superação da negatividade, pelo movimento dialético de superaçáo da oposiçáo.

Entretanto, quando Marx fala, a respeito do capital, de um "sujeito automático", constrói um paradoxo. O conceito de capital exprime um "sujeito objetivo", que se utiliza da produção real como mediação em sua autorreprodução. Isto é, o capital é o sujeito do processo, e não o homem. Vemos, aqui, como o problema com o qual Marx se depara é aquele da inversão do humanismo e da crítica da antropologia. Ideologicamente, o capitalismo é fundamentado no humanismo, nos Direitos do homem, na produção "real"; efetivamente, contudo, o agente da produção, aquele para o qual a produção é realizada, é a abstração monetária, isto é, o capital, o qual aparece como causa primeira e final do processo de produção.

Se, em Hegel, tal processo de alienação da produção em um outro deveria resultar na superação, no progresso histórico, a virada na obra de Marx, dos escritos humanistas para o capital, ocorre quando ele recusa tal esquema. Ou seja, Marx passa a relacionar o próprio conceito de capital àquilo que Hegel chama de "espírito absoluto", ao final de sua Fenomenologia, ou de "conceito", ao final da Ciência da lógica (2011). Trata-se, na intepretação de Marx, da estrutura idealista da dialética hegeliana: o movimento de resolução dos antagonismos, de síntese dos contrários, é operado idealmente, através de um agente trans-histórico capaz de garantir que a negatividade será resolvida, que o antagonismo será reconduzido a uma nova identidade. Na leitura de Marx, 
tal agente, capaz de prometer, a partir do negativo e da alienação, a reconciliação histórica, passa a constituir o próprio capital.

Daí a ideia de Marx de que a dialética hegeliana deveria ser colocada "de cabeça para cima", conforme as palavras do prefácio à segunda edição de O capital (MARX, 2010b, p. 29). É o caso de reconduzir o processo para seu verdadeiro agente - o proletariado. Podemos dar o exemplo, aqui, daquilo que alguns comentadores pensam como sendo o erro da avaliação hegeliana da estrutura produtiva do mundo moderno (JAMESON, 2010). Enquanto a produçáo já era hegemonicamente determinada pela indústria, Hegel ainda a pensava conforme o modelo da manufatura.

Ora, tal erro, para Marx, longe de ser acidental, relaciona-se com o próprio idealismo hegeliano. De fato, sabe-se que a substituição da manufatura pela indústria propriamente moderna dá-se quando a autonomia do produtor é subordinada a um processo de produçáo que tem, em seu centro, a produção do valor de troca e a automação do maquinário. Isto é, o produtor é destituído de sua autonomia, e passa a trabalhar para outro. Se Hegel enxergava homens produzindo onde havia, na verdade, máquinas, é porque, dentro de seu próprio sistema de pensamento, ele desprezava o papel fundamental do homem no processo histórico. Seu erro teórico era, assim, a imagem invertida de um erro histórico, empírico. Se, na teoria, Hegel colocava a transcendência do Espírito, ou da substância, como agente, na história, enxerga homens no lugar de máquinas.

Ora, enxergar homens no lugar de máquinas é o erro, segundo Marx, da própria ideologia capitalista; esta consiste em afirmar o "humanismo" do direito dos homens, da democracia, enquanto a produção é toda determinada pelo mecanismo impessoal do capital. É por isso que o proletariado, como classe que produz, constitui o momento inerente de subjetivação do idealismo moderno. Marx precisa da categoria de um sujeito de classe (o "proletariado"), a partir da qual centrar o processo histórico "sobre seus próprios pés"; assim como, a respeito da dialética e de Hegel, precisava reconduzir o Espírito à sua verdadeira causa.

O movimento do capital pertence à categoria que Marx (2010b) chama de "abstração real". Ele parece ser um sujeito que póe sua própria alteridade para recuperá-la em níveis cada vez maiores, engendrando-se em função de suas próprias crises, utilizando-se de seus antagonismos como escadas para novos ciclos produtivos, saindo cada vez mais vitorioso daquilo que parece- 
ria aniquilá-lo. No entanto, na figura do proletariado, Marx encontrou um escândalo para a racionalidade do capital, que, em sua leitura, significa também um escândalo para a dialética hegeliana: o próprio corpo produtivo, verdadeiro agente do processo social e histórico. E o desprezo capitalista pelo corpo do proletariado representa, portanto, um desprezo da sociedade capitalista como tal pela materialidade; a abstração monetária, comandando o processo social como esse "sujeito automático" a respeito do qual Marx fala, nos Grundrisse, condena o corpo daqueles que produzem, de forma que o proletariado se torna esse

\begin{abstract}
completo desnudamento do trabalho, existência puramente subjetiva, desprovida de toda objetividade. $\mathrm{O}$ trabalho como a pobreza absoluta. A pobreza não como falta, mas como completa exclusão da riqueza objetiva. $\mathrm{Ou}$, ainda, como o náo valor existente e, por conseguinte, valor de uso puramente subjetivo, existindo sem mediação. Tal objetividade só pode ser uma objetividade não separada da pessoa: apenas uma objetividade coincidente com sua imediata corporalidade. (MARX, 2011, p. 230).
\end{abstract}

Desta maneira, uma das principais acusaçóes de Marx a Hegel é a de que este haveria negligenciado, em seu sistema, a materialidade, privilegiando o conceito, a abstração. É desta foram que os agentes históricos terminariam sendo tragados pelo "círculo dos círculos" do movimento dialético, transformados em mero meio, mediação que permite à totalidade da ideia realizar-se, um apêndice da máquina lógico-idealista, assim como, no capitalismo, os trabalhadores são apêndices da maquinaria industrial, portanto. Marx aponta como o capital é fundamentalmente impotente para interiorizar o proletariado, pela simples razão de que depende dele, dessa contingência corporal que é a causa, a verdadeira raiz do processo de produção. O trabalho vivo da classe proletária é o "fermento que é jogado no capital e produz sua fermentação." (MARX, 2011, p. 232).

O automovimento do capital é apenas uma abstração objetiva, o modo como a sociedade parece ser estruturada, a descrição elaborada por Marx daquilo que constitui a ideologia do capitalismo, e não o real do processo produtivo. A verdade, a raiz desse movimento aparentemente absoluto e capaz de interiorizar quaisquer barreiras, é o corpo produtivo do trabalhador, de uma classe social que, sendo condição de toda riqueza, encontra-se despossuída da riqueza objetiva, concreta. E essa estranha mistura de abstração e materialidade, de um sujeito ao mesmo tempo produtor de riqueza e despossuído de toda riqueza, constituiria o ponto cego do sistema hegeliano. 
Portanto, a reversão do idealismo hegeliano implementada por Marx é simétrica à sua busca pela reversão materialista do capitalismo. Os dois teriam cometido o mesmo erro fundamental: haveriam "esquecido" de um resto que mancha o sistema, constituindo sua condição não reconhecida de possibilidade. Resto que é identificado ao trabalho vivo, à materialidade que é abstraída, reduzida a apenas um momento no movimento ideal do sistema, de modo que "o processo de trabalho [...] posto antes do valor, como ponto de partida, reaparece no interior do capital, como um processo que se desenrola no interior de sua matéria." (MARX, 2011, p. 237).

O caráter ideológico do capitalismo associa-se à ideia de que o sistema será capaz de mediar/interiorizar todos seus antagonismos, propondo uma síntese que pacificaria as relaçóes sociais marcadas pelo antagonismo de classe. Isto é, a ideologia procura garantir que a negatividade (Negativität), o "trabalho do negativo" (HEGEL, 1992) representado não somente pela diferença de classes, mas também pela separação entre produção e abstração, materialidade e ideia, poderá ser continuamente (re)mediado.

Ora, o problema é que tal separação é engendrada pelo próprio capitalismo - isto é, o capital procura curar o mal que ele próprio produz. Ideologicamente, há um agente maior ("o capital"), capaz de servir de garantia de que, no final do processo, existirá a reconciliação social, já que o conflito social tem um papel produtivo no próprio desenvolvimento da sociedade. As diferenças de classe são a pré-condição para o impulso por desenvolvimento, assim como as diversas crises que atravessam a sociedade, da crise ambiental às crises "humanitárias", servem ao capital como obstáculos, a partir dos quais ele poderá se aperfeiçoar.

\section{APENAS O CÍNICO PODE SER VERDADEIRAMENTE HUMANISTA}

Nesse sentido, o capitalismo é, de fato, capaz de justificar, de maneira ao mesmo tempo cínica e humanista (veremos como ambos são complementares, para Marx), a desigualdade social produzida pelo sistema. Como argumentaram diversos autores, desde o estudo pioneiro de Peter Sloterdijk (1988) sobre a razão cínica, as formas tradicionais de crítica da ideologia, as quais buscaram revelar a negatividade inerente a qualquer sistema universal de valores, tornam-se ineficazes na atual conjuntura histórica (SAFATLE, 2008; ZIZEK, 1991). A ideia de uma razão cínica significa fundamentalmente que a ideologia atual é capaz de reconhecer, 
sem com isso se ver obrigada a qualquer gesto de transformação estrutural, que a "contradição social" é gerada pelo próprio capitalismo, sendo condição para seu funcionamento "normal".

A maneira tradicional de se criticar o capitalismo busca revelar como este depende, para produzir em escalas cada vez mais alargadas, da criaçáo de miséria, da depredação do meio ambiente, de guerras e dominação entre estados e classes sociais. Nesse sentido, ela pretende mostrar como a universalidade do capital é manchada pelo negativo; que, por exemplo, a luta pela universalidade dos direitos humanos é uma máscara usada por uma determinada classe, para obter hegemonia política e econômica.

Todavia, tal crítica termina, hoje, por bater em uma porta aberta, já que o sistema é plenamente capaz de admitir seu caráter "contraditório". Este constituiria, inclusive, a razáo de sua eficácia. Não somente que uma classe queira dominaçáo econômica, mas que ela possa hipocritamente falar em nome do interesse coletivo, quando, na verdade, apenas busca afirmar o ponto de vista particular de seus interesses, não constitui, dessa forma, qualquer razão de escândalo (SAFATLE, 2008, p. 101).

Trata-se de um sistema que, por si mesmo, entregue a seu funcionamento automático, já é capaz de contrabalançar seus próprios excessos, através da dependência multilateral dos produtores e proprietários individuais. Afinal, os capitalistas como classe dependem do proletariado para consumir seus bens, como mostram as crises de superprodução tão bem analisadas pelo próprio Marx. É nesse sentido, pois, que o cinismo capitalista, compreendido por Marx como forma ideológica de legitimação da exploração social, é também plenamente humanista. Na verdade, a ideia de Marx é a de que apenas o sujeito humanista pode ser plenamente cínico (MARX, 2010b, p. 206, 266). O cinismo constitui o argumento de que os obstáculos, o "negativo", são parte fundamental no processo de emancipação material e social, que todo limite poderá ser convertido em condição para uma nova expansão, a qual, por sua vez, gerará uma nova barreira, e assim ao infinito.

Zizek define com precisão a ideologia cínica, ao apontar como esta já funciona como uma espécie de "negação da negação" dialética, em que o negativo é incluído como momento fundamental no progresso social. Segundo o filósofo, 
este cinismo é, portanto, uma espécie de "negação da negação" pervertida da ideologia oficial: confrontada com o enriquecimento ilegal, com o roubo, a reação cínica consiste em dizer que o enriquecimento legal é muito mais eficiente e, ademais, está protegido pela lei. Como Bertold Brecht diz em sua Ópera de três vinténs: "O que é o roubo a um banco comparado com a fundação de um novo banco?” (ZIZEK, 1991. p.346).

A crítica dirigida por Marx ao movimento do capital é a de que a realização da causa comum é fundamentalmente idealista. Ela não representa a realizaçáo do sujeito concreto, histórico, porém, a de uma entidade abstrata chamada "capital", que deve sempre sair vencedora, enriquecida, em razão de suas crises, independentemente do estatuto social concreto dos sujeitos. E o cinismo consiste em responder que é exatamente devido a seu caráter abstrato, à fiç̧ão de um agente autônomo capaz de se apropriar da materialidade e pô-la como alteridade através da qual ele se medeia e se enriquece, que o sistema adquire sua real eficácia.

Paradoxalmente, se podemos caracterizar o capitalismo com a ideia de uma sociedade pós-ideológica, não se trata do argumento de que toda e qualquer ideologia seria suplantada em nome da realidade ou da verdade. Pelo contrário, a noção de sociedade pós-ideológica significa o pleno reconhecimento social da necessidade da ideologia, através da recusa da possiblidade do sujeito finito de atingir qualquer emancipação. Ideológico será, portanto, todo discurso que tenha a pretensão de desfazer a ideologia, em nome da realização de qualquer verdade.

$\mathrm{O}$ argumento cínico busca afirmar a necessidade do engano, da ilusão e da desigualdade como tendo papel estrutural no progresso social. A noção de que viveríamos em uma sociedade pós-ideológica não significa, nesse sentido, que a ideologia tenha acabado, mas sim que a necessidade da ideologia pode ser, enfim, plenamente aceita. $\mathrm{O}$ sujeito, como ente finito, não tem acesso a qualquer espécie de totalidade ou de reconciliação; a ele cabe, por conseguinte, reconhecer a ideologia como parte inerente da conduta humana. Obviamente, o sentido contemporâneo e positivo de ideologia muda completamente, em relação à concepção crítica de Marx, aproximando-se mais daquilo que, no movimento pós-estruturalista dos anos 60 e nas teorias influenciadas por seus autores, se costuma chamar de simulacro, ou semblante (DELEUZE 2006; LYOTARD, 2015): a virtualização absoluta das identidades sociais sem o peso ontológico de entidades metafísicas como a verdade ou a realidade. 


\section{HumANISMO E SUBJETIVIDADE}

Uma das maneiras de abordarmos o conceito de ideologia, em Marx, é por intermédio da análise da transição entre a perspectiva humanista de seus escritos de juventude e o desenvolvimento do conceito de capital, nas obras tardias. Tal passagem foi proposta, principalmente, pela leitura estruturalista de Althusser (1969, p. 219-249): entre a Critica da filosofia de Hegel (MARX, 2010a), representante daquilo que Althusser caracteriza como o momento humanista da teoria, e $O$ capital (MARX, 2010b), há o corte no qual Marx rompe, de fato, com os pressupostos hegelianos de seu método anterior, fundando uma nova ciência, o marxismo propriamente dito.

Entretanto, alguns intérpretes, como Slavoj Zizek (2013), afirmam que é justamente em sua obra madura que Marx, longe de romper definitivamente com Hegel, na verdade, se aproxima do Hegel "verdadeiro". Zizek chega a defender, nesse sentido, que "a inovação crucial na obra de Marx ocorreu em meados da década de 1850, quando, depois do fracasso das revoluçóes de 1848, ele começou a reler a Lógica de Hegel.” (ZIZEK, 2013, p. 95). De qualquer maneira, podemos ver como a intepretação do legado hegeliano é central à intepretação da filosofia marxista, de sorte que devemos perguntar o que ocorre nesse entretempo quando foi gerado o conceito propriamente marxista de capital, e qual a importância da releitura da lógica hegeliana, nesse processo.

Podemos dizer, com Zizek, que o fracasso dos movimentos operários e socialistas, no final dos anos 1940, é fundamental ao rompimento de Marx com sua perspectiva humanista anterior e à necessidade de retornar a Hegel, a fim de reelaborar sua teoria. Marx percebe que a crítica da ideologia capitalista não poderia ser concretizada a partir do pressuposto humanista e evolucionista de um sujeito capaz de recuperar-se historicamente da alienaçáo social gerada por sua própria atividade, capaz de se apropriar de sua produção exteriorizada em uma estrutura histórica estranha.

Para Althusser (1969), a transformação de Marx, após seu primeiro momento humanista dos anos 40 e 50, dá-se através da constatação de que o movimento histórico não decorre da exteriorização/alienação do homem, dentro de uma estrutura histórica determinada, e de sua subsequente reapropriação daquilo que fora exteriorizado. O que Marx percebe, então, é que essa estrutura de promessa, a barganha segundo a qual o negativo seria condição para o sujeito atingir uma positividade posterior, já constitui a ideologia propriamente capitalista. 
Isto é, quando Marx (2010b) elabora plenamente sua crítica do capitalismo, em $O$ capital, esta termina por ser igualmente uma autocrítica. Sua ideia, em seus escritos de juventude, era a de que o movimento histórico de negação constituía uma etapa fundamental de alienação do sujeito, que deveria criar as condiçóes para que a produção alienada pudesse ser recuperada, em uma sociedade sem classes. Ora, podemos ver como esse movimento descreve perfeitamente o mesmo movimento cínico e humanista que Marx passa a atribuir ao capitalismo: a ideia de que o negativo é condição fundamental para o progresso das forças e relaçóes de produção.

A partir de tal crítica, de fato, duas possibilidades parecem se abrir, como intepretação do sujeito histórico. Uma delas consiste em afirmar a ideia de uma substância produtiva primeira, fundamentando a construção de uma nova sociedade, livre das barreiras históricas/finitas das relações de produção de classe. Esta nos parece ser a intepretação do pós-marxismo de autores autonomistas como Negri e Hardt (2000) ou, ainda, do marxismo antidialético elaborado por Deleuze e Guattari (2010), em $O$ anti-Édipo. Comum a esses autores é a caracterização do sujeito através de categorias como potência e desejo revolucionário, dentro das quais a negatividade dialética não possui qualquer papel constituinte, representando antes a captura, o bloqueio, do livre desenvolvimento da potência produtiva.

Outra perspectiva consiste em constatar, paradoxalmente, que aquilo que é perdido é perdido para nada; ou seja, que a ideia de que a negação poderá levar o sujeito a uma positividade posterior, assim como a de que haveria uma produtividade primária que seria corrompida, bloqueada pelos sistemas sociais, constitui a estrutura fundamental da ideologia. Esta nos parece ser a tese comum às intepretaçóes de Marx influenciadas pela psicanálise lacaniana, como em Zizek (2013) e Badiou (1988), mas também já presente em alguns elementos da filosofia de Adorno (1984) e na leitura que Lacan (2008) oferece de conceitos marxistas, como o de mais valia.

A respeito desse debate, parece-nos que Marx não responde plenamente a esse problema. Em seus escritos tardios, ele parece oscilar entre dois caminhos, entre duas concepçóes de produção. Por um lado, no Prefácio para a crítica da economia politica (MARX, 2012, p. 267-275), por exemplo, temos a ideia de uma força produtiva determinante, a qual haveria sido alienada/ exteriorizada e poderia ser recuperada. Trata-se daquilo que Derrida (1993) caracteriza, em Espectros de Marx, como sendo a fantasia fundamental não 
desconstruída do marxismo (presente, inclusive, no socialismo soviético): a de um valor de uso pleno que poderia ser reintegrado.

Por outro, contudo, há a constatação aparentemente "niilista" de que tanto a ideia de uma produtividade primária quanto a da negatividade condição do desenvolvimento histórico podem ser, ambas, negadas como ideológicas. É essa perspectiva que, como veremos adiante, reaproximaria Marx da dialética hegeliana.

Essa segunda resposta gera, entretanto, um novo problema: como definir, agora, o sujeito de classe, se já não podemos contar com o pressuposto humanista do Marx jovem, o qual identificava no homem que produz o núcleo materialista do próprio pensamento? É esse o mesmo problema que podemos encontrar na intepretaçáo estruturalista de Althusser, quando este opóe o domínio da ideologia como sendo o da ilusão individualista ao da ciência, não contaminada pela subjetividade. Isso significa, para Althusser, enfatizar o corte epistemológico entre as obras de juventude do Marx humanista e a ciência madura, em $O$ capital, onde a categoria genérica de "homem" não teria qualquer serventia. É nesse sentido que Althusser pode afirmar que, em Marx “o conceito de 'socialismo' é, de fato, um conceito científico, enquanto o conceito de 'humanismo' não é mais do que ideológico.” (ALTHUSSER, 1969, p. 223).

Entretanto, não sacrificaríamos, assim, a possibilidade de pensar aquilo que não seria a ideologia, isto é, o papel do sujeito produtivo na história? De fato, é a respeito desse suposto sacrifício do sujeito de classe que foram elaboradas as críticas humanistas ao Marx de $O$ capital. Segundo estas, Marx teria, através da exposição sistemática do capitalismo, perdido a própria subjetividade operária, esta que tinha papel protagonista em seus primeiros escritos. Tal perspectiva, que tende a privilegiar o Marx de juventude, critica $O$ capital por terminar construindo a ideia de um sistema fechado, no qual não se vê mais como o proletariado poderia ser incluído como agente histórico de transformação.

Temos, pois, de um lado, o humanismo dos primeiros anos de Marx, que, conforme sua própria avaliação posterior, termina sendo cínico, já que ancorado na ideia da exploração como mediação para o progresso. Por outro, há o "cinismo" dos anos de maturidade, que parece excluir o papel ativo do sujeito de classe: ao descrever o funcionamento do capital como uma espécie de espírito absoluto hegeliano, Marx terminaria por recair naquilo que anterior- 
mente criticara ao próprio Hegel, esquecendo a maneira como a subjetividade é o fundamento da abstração, e não o contrário.

Ora, e se, longe de propor como solução para esse problema, por meio da noção evolucionista das forças produtivas como determinantes do progresso histórico, ancoradas na própria natureza produtiva do homem (como o próprio Marx, por vezes, parecia querer), aceitássemos as consequências radicais da autocrítica do Marx tardio? Se recusarmos tanto a ideia de uma força produtiva, que seria a causa do progresso histórico, quanto a de que a negatividade constitua qualquer tipo de motor da evolução social, é pela absoluta ausência de qualquer base ontológica capaz de fundamentar a história que emerge o sujeito revolucionário. Ora, mas tal ideia parece, como veremos agora, estranhamente próxima àquilo que Hegel chama de "negatividade absoluta." (HEGEL, 2011, p. 276).

Nessa outra interpretação da negação, não apenas deixa de haver a figura de uma positividade inerte alheia ao sistema, uma substância imediata que haveria sido perdida, limitada. Da mesma forma, é a própria noção de que, por essa perda, um novo positivo poderia ser gerado, que através do movimento de negação haveria a produção de estágios historicamente mais desenvolvidos, a qual é recusada. Ou seja, o proletariado, como sujeito esvaziado de sua produçáo, alienado de sua própria subjetividade pela exploração social, não adquire nada por intermédio dessa perda ou alienação.

Mas, se aquilo que o sujeito busca recuperar só existe, só é criado por esse movimento de perda, a única maneira de representar, de inscrever o sujeito dentro da ordem social é com a ideia hegeliana dessa "negatividade absoluta" (absolute Negativität) (HEGEL, 2011, p. 276). Não no sentido abstrato de uma pura negação (abstrakte Negativität), porém, no sentido especulativo de uma negação imanente ao próprio absoluto, uma negação autorrelativa, que não pede para ser resolvida em um estágio historicamente posterior, ou "mais elevado". Negação que corresponderia, então, ao conceito hegeliano de sujeito.

A crítica da ideologia, nesse sentido, consiste em retirar ao sujeito de classe até mesmo aquilo que ele pensava possuir - seus potenciais interiores precedentes à captura, sua produção historicamente bloqueada -, assim como se trata de recusar a ideia de que negação, a exploração, constituiria qualquer tipo de condição para a libertação. Lidamos aqui, portanto, justamente com o inverso da concepçáo do Marx humanista anterior, que enxergava na alienação 
e na exploração históricas a condição para a reapropriação ulterior da produção, em uma sociedade sem classes.

\title{
Hegel E O SUJeito VAZio
}

Agora podemos ver como a Ciência da lógica de Hegel foi fundamental a esse movimento, e por que Marx precisou relê-la, antes de compreender o funcionamento básico do capitalismo. Basta lembrar teses como aquela que Hegel defende, na seção da essência na Ciência da lógica, sobre a relação entre a reflexão e o mundo exterior imediato, o ser:

\begin{abstract}
A imediaticidade surge apenas em geral como retorno e é aquele negativo que é aparência do início, que é negado por meio do retorno. O retorno da essência é, assim, seu rechaçar-se a si mesma. Ou a reflexão em si é essencialmente o pressupor daquilo de que ela é o retorno. [...] Este algo encontrado diante dela apenas se torna algo quando é abandonado. (HEGEL, 2011, p. 121-122).
\end{abstract}

Nesse trecho, Hegel afirma que a primeira negação, através da qual o sujeito perde a positividade do ser imediato, a essência vivida, a qual se torna seu oposto na abstração fria do entendimento que tenta capturar o ser em categorias de pensamento, não é um trampolim, um mediador, para que o sujeito retorne ao imediato. O papel da mediação ou da negaçấo, em Hegel, não é a de desparecer, uma vez que seu trabalho tenha sido realizado, permitindo a reconciliação dos opostos. O que desaparece é, antes, a positividade em relação à qual o negativo seria um mediador. Ou, como coloca Hegel, na passagem, "o retorno da essência é, assim, seu rechaçar-se a si mesma.”

Assim, quando Hegel (2011, p. 278) afirma que "o terceiro é o imediato, mas por meio da superação da mediação", podemos ler a "superação da mediação" como o desaparecimento da negação, devido à produção de um novo positivo sem qualquer outro, capaz de interiorizar qualquer alteridade como momento em seu processo de determinação. Entretanto, tal leitura perde o sentido da ideia de Hegel, que consiste em mostrar como a superação da mediação, ou do negativo, só ocorre através de um redobramento, de uma repetição do negativo - repetição por meio da qual é o negativo que passa a constituir o sujeito do processo dialético, e não a teleologia da reconciliação dos contrários: 
Esse resultado é, por conseguinte, a verdade. É, igualmente, a imediatidade como mediação. [...] Pois ele [o resultado do processo, isto é, o positivo] não é o terceiro tranquilo, e sim justamente como essa unidade é o movimento e a atividade que se medeiam consigo mesmos. (HEGEL, 2011, p. 278).

Por isso, Hegel chama esse resultado do processo de "negatividade absoluta" ou, como vimos acima, de uma negação autorrelativa, a qual não se contenta em negar um outro, mas nega a si própria. A negação não é o terceiro que medeia duas positividades, ela não teria um papel de mediação externa, formal, devendo desaparecer ao final do processo. A ideia de Hegel é justamente a contrária: tornar o negativo o fundamento do processo, a "essência rechaçada", a qual apenas encontra a si mesma através daquilo que é absolutamente outro.

Aquilo que Hegel chama de negação da negação implica, portanto, uma mudança completa de ponto de vista. Como frisa Hegel, na seção da essência, "o devir da essência, seu movimento reflexionante [o passar da essência imediata para a reflexão 'exterior' subjetiva] é, assim, o movimento do nada para o nada e, desse modo apenas para si mesmo de volta." (HEGEL, 2011, p. 119). Não se trata mais do negativo como ponte, como mediação entre duas positividades, mas do negativo como absoluto, o qual medeia a si mesmo, nega a si mesmo. Essa automediação do negativo já é, para Hegel, o positivo.

A segunda mediação, o negativo do negativo, tem o papel de cancelar a ilusão do primeiro positivo, subordinando-a ao movimento da própria negação. Se o negativo "aparece como mediador" é porque

engloba a si mesmo e o imediato em si, cuja negação ele é. Na medida em que essas duas determinações segundo qualquer relação, são tomadas como relacionadas externamente, ele é apenas o formal mediador; como negatividade absoluta, porém, o momento negativo da mediação absoluta é unidade que é subjetividade e alma. (HEGEL, 2011, p. 276).

Isto é, o processo dialético busca inverter o ponto de vista segundo o qual o positivo apareceria como universalidade que engloba a ela mesma e ao negativo, afirmando o movimento contrário: é o negativo que "engloba a si mesmo e o imediato em si, cuja negação ele é.” (HEGEL, 2011, p. 276). Desse modo, como Hegel salienta nessa passagem, a mediação deixa de ser 
formal, exterior, para tornar-se real, concreta, a "subjetividade e alma" como o sujeito do processo.

Este é o sentido, então, da famosa frase do prefácio aos Princípios $d a$ filosofia do direito: "Quando as sombras da noite começam a cair é que levanta voo o pássaro de minerva." (HEGEL, 1998, p. XXXIX). A compreensão usual dessa frase, assumida pelo próprio Marx, é a de que, para Hegel, a filosofia ocuparia a posiçấo de fiadora do dilaceramento, da luta e dos conflitos aparentemente irreconciliáveis. De sua perspectiva mais elevada, ela é capaz de enxergar que a negatividade é um meio, uma mediação fundamental à produção da reconciliação.

A tarefa da filosofia seria, assim, a de reconhecer a necessidade oculta por trás daquilo que aparece para a consciência comum como sendo apenas um movimento caótico e aleatório, uma negação sem retorno e sem reconciliação. Tal perspectiva corresponde à posição do Sábio capaz de enxergar, no caos e na contingência da vida ordinária, a presença de um sentido dentro do qual o negativo aparece como caminho fundamental no aperfeiçoamento, no progresso histórico. ${ }^{2}$

Ora, tal é a característica que vimos acima como constituindo o elemento ao mesmo tempo cínico e humanista atribuído por Marx ao próprio capitalismo: este é o absoluto capaz de garantir que, através das crises, um novo positivo será gerado. Mas a ideia de Hegel, como temos visto, é justamente a oposta daquela que enxerga a filosofia como devendo assumir a posição do sábio que consegue dar a intepretação global que unifica a luta de agentes parciais, incapazes de enxergar o sentido maior de suas açóes. A filosofia como "coruja de Minerva" não leva o sujeito a reconhecer a ação de uma necessidade maior por trás do teatro de aparências, porém, ao redobramento, à repetição da própria contingência, que deve eliminar a ilusão ideológica fundamental: a de que haveria uma positividade ulterior como recompensa pelos sacrifícios, uma necessidade subjacente que estaria guiando o processo histórico.

\footnotetext{
${ }^{2}$ Esta nos parece constituir a leitura que Kojéve faz de Hegel, para o qual o fim da história corresponderia ao advento do filósofo como "homem sábio". Cf. Introdução à leitura de Hegel: "No fim da história, [...] a consciência de si filosófica do cidadáo desse Estado final revela a totalidade da vida cultural e política real. [...] logo, o religioso deixa de ter razão de existir e desaparece. Mas essa destruição da Gegenständlichkeit (condição de objeto-coisa), isto é, da realidade divina, é ao mesmo tempo a afirmaçáo da realidade humana; a realidade negada como divina e afirmada como humana é a mesma. Nesse momento, o filósofo é um sábio, e a filosofia é sabedoria ou ciência." (HEGEL, 1947, p. 288, tradução nossa).
} 
A ideia da dialética é a de que a negatividade já é parte inerente do absoluto, que o movimento aparentemente contingente, acidental, histórico, de negação somente pode ser superado quando o reinscrevemos na própria essência, quando o elevamos à necessidade da essência. Dessa maneira, o absoluto hegeliano, longe de constituir a universalidade capaz de interiorizar qualquer contingência/exterioridade, é aquela que é capaz de reconhecer aquilo que ela não pode mediar, interiorizar, a radical contingência de uma negatividade que permanece sendo exterior, conforme ressalta Catherine Malabou, em seu estudo sobre Hegel:

A filosofia de Hegel torna possível observar a passagem de um modo de recolhimento/reunião [gathering] ontológico para outro: da operação transcendental da consciência para o mecanismo de singularidades em sua distribuição automática. [...] $\mathrm{O}$ espaço aberto por essa dinâmica não requer a intervenção de um Ego: é o trabalho de ninguém [no one]. (MALABOU, 2005, p. 165, tradução nossa).

O que não significa, então, que tal "trabalho de ninguém” seja o trabalho ideal do absoluto como interiorização de toda particularidade/singularidade, mas que "ninguém" [no one] já é o nome hegeliano para o sujeito. Como negatividade absoluta, o sujeito é capaz de inscrever, de elevar essa singularidade contingente que lhe escapa ao próprio universal.

\section{Entre Hegel e Marx.}

Isso significa que, quando Marx se afasta de seu ponto de vista humanista de juventude, longe de afastar-se de Hegel, como ele mesmo pensara, ele termina por encontrar o verdadeiro sentido da dialética. Quando pensa descrever o próprio absoluto de Hegel como já sendo o movimento do capital, Marx formula a própria versão hegeliana da "crítica da ideologia". Quer dizer, a crítica daquilo que Hegel (1991) chama de "entendimento" (Verstand), o ponto de vista da reflexão externa e formal, que acredita ainda em um sentido subjacente por trás da forma, em um "ser-em-si" (sein-an-sich) que haveria sido perdido no "ser-para-outro" (sein-für-anderes) da reflexão.

E se Marx, relendo Hegel, houvesse se deparado com a possibilidade de articular a ideia do movimento de negação da negaçáo não como recuperação e síntese, mas justamente como essa negatividade absoluta (absolute Negativität) capaz de pensar aquilo que o capital não pode interiorizar ou mediar, 
uma negatividade que toca o próprio absoluto? Trata-se da possibilidade de se pensar um sistema histórico no qual a negatividade não se torne oculta, negada por qualquer estrutura ideológica de recuperação, por qualquer teleologia do agente abstrato capaz de transformar a contingência em necessidade, o negativo em positivo.

Pensamos, por conseguinte, que esse sentido radical da dialética é aquilo que Marx encontra, quando elabora sua crítica da ideologia capitalista: a radicalização "niilista" da negatividade é capaz de limpar o terreno da ideologia, confrontando o sujeito com a radical contingência da exploraçáo histórica, com o caráter fundamentalmente arbitrário de sua servidão. Logo, é tal radicalização do negativo que Marx ainda não formula satisfatoriamente, quando abandona o pressuposto humanista do sujeito produtor. Ao invés de tirar as consequências últimas de sua análise do capital, ele oscila entre a ideia de uma produção ilimitada, a-histórica, e a pura negação do sujeito histórico no movimento automático da abstração capitalista.

Constituem, na verdade duas posiçôes correlatas, já que a ideia de um sujeito produtivo primário parece ser a única resposta adequada à impotência em relação ao qual a subjetividade é confrontada, quando enxerga no capital essa máquina impessoal capaz de mediar qualquer alteridade. A terceira opção, que não nos parece plenamente articulada em Marx, é, portanto, aquela que Hegel buscou pensar. Recusar qualquer estrutura de antecipação que legitimaria ou justificaria o sofrimento social, longe de significar a conclusão desesperada de que não há nenhuma saída da exploração, torna o sujeito capaz de quebrar a ideologia sobre a qual se assenta o funcionamento do próprio capitalismo, a crença a partir da qual o sujeito constrói sua adesão ao sistema.

Desse modo, criticar a ideologia é compreender que não há nenhum sistema que garanta uma recompensa pelo sacrifício. Trata-se do encontro com o caráter radicalmente não justificado do sofrimento, onde se perde aquilo mesmo em prol do que se sacrifica, enxergando como o sacrifício é realizado em vão. Segundo Hegel, é através dessa conclusão radical, dessa reafirmação do negativo, que o sujeito pode, pois, sacrificar o próprio sacrifício. E isso corresponde à ideia de que a negação da negação, em Hegel, não significa que seria pelo sofrimento que o sujeito é formado para o absoluto e para uma reconciliação, mas justamente o oposto. Negando a negação, o sujeito descobre que seu sacrifício não valera para nada, que não há nenhuma reconciliação, esperando no fim da história, como prêmio pela negatividade presente. 
Isto seria, por conseguinte, aquilo que Hegel chama de espírito absoluto (absolute Geist). Não a descoberta de uma necessidade subjacente à contingência radical da história, a justificação filosófica de que o dilaceramento seria o motor para o desenvolvimento, da formação para o Espírito, porém, de fato, o reconhecimento de uma contingência radical. $O$ ponto de vista do saber absoluto não cancela o sofrimento histórico. Se a "razão é a rosa na cruz do sofrimento presente" (HEGEL, 1997, p. XXXVIII), não é porque ela embeleze ideologicamente aquilo que o sujeito não pode suportar, mas porque ela é capaz de reconhecer, justamente na ausência de justificativa do sofrimento, o próprio ponto de vista do absoluto como possibilidade da transformação.

LAUREANO, P. Repetition, negation, and ideology: Marx, Hegel, and the problem of the subject. Trans/form/ação, Marília, v. 41, n. 3, p. 105-124, Jul./Set., 2018.

ABSTRACT: This article starts with an analysis of the influence of Hegel on the construction of the concepts of capital and ideology in Marx's work. To this end, we analyze the transition from Marx's first humanist writings to his later theory. Due to the break achieved by Marx in relation to his early works, a problem arises: the determination of the revolutionary subject once the initial humanist perspective has been abandoned. Our thesis is that when Marx leaves Hegel, he paradoxically ends up encountering problems (such as the question of the critique of ideology) that can only be resolved by Hegelian dialectics. We argue this by means of an analysis of the role of negativity in Hegel.

KeYwords: Marx. Hegel. Dialectics. Ideology.

\section{REFERÊNCIAS}

ADORNO, T. Dialética negativa. Madrid: Taurus, 1984.

ALTHUSSER, L. For Marx. London: The Penguin Press, 1969.

BADIOU, A. O ser e o evento. Rio de Janeiro: Jorge Zahar, 1988.

DELEUZE, G. Nietzsche e a filosofia. Porto: Rés-Editora, 2001.

. Diferença e repetição. Rio de janeiro: Graal, 2006.

DELEUZE, G.; GUATTARI, F. O anti-Édipo. São Paulo: Editora 34, 2010.

DERRIDA, J. La différance. In: Théorie densemble. Paris: Seuil, 1968. p. 41-66. 
. Spectres de Marx. Paris: Galilée, 1993.

. A Escritura e a diferença. São Paulo: Perspectiva, 2009.

HEGEL, G. W. F. Princípios da filosofia do direito. São Paulo: Martins Fontes, 1997. . Fenomenologia do espírito. Petrópolis: Vozes, 1992.

. Ciência da lógica. São Paulo: Barcarolla, 2011.

JAMESON, F. The Hegel variations: on the phenomenology of spirit. New York: Verso Books, 2010.

KOJÈVE, A. Introduction à la lecture de Hegel. Paris: Gallimard, 1947.

LACAN, J. O seminário, livro 16: de um outro ao outro. Rio de Janeiro. Jorge Zahar, 2008.

LYOTARD, J. A condição pós-moderna. Rio de Janeiro: José Olympio, 2011.

MALABOU, C. The future of Hegel: plasticity, temporality and dialetic. New York: Routledge, 2005.

MARX, K. Manuscritos econômico-filosóficos. São Paulo: Boitempo, 2004.

. Crítica da filosofia do direito de Hegel. Sáo Paulo: Boitempo, 2010a.

. O capital: crítica da economia política. Rio de Janeiro: Civilização Brasileira, 2010b. Livro 1.

. Grundrisse. São Paulo: Boitempo, 2011.

. Prefácio a "Para a crítica da economia política”. In: PAULO NETTO, J. (Org.).

O leitor de Marx. Rio de Janeiro: Civilização Brasileira, 2012.

NEGRI, A.; HARDT, M. Império. Rio de Janeiro: Record, 2000.

SAFATLE, V. Cinismo e falência da crítica. São Paulo: Boitempo, 2008.

SLOTERDIJK, P. Critique of cynical reason. Minneapolis: University of Minnesota Press, 1988.

ZIZEK, S. O mais sublime dos histéricos: Hegel com Lacan. Rio de Janeiro: Jorge Zahar, 1991. - Menos que nada: Hegel e a sombra do materialismo dialético. São Paulo:

Boitempo, 2013.

Recebido: 2015-08-21

Aceito: 2016-08-23 